\title{
Rare case of sarcoidosis presenting with pancytopenia, acute renal failure and hypercalcaemia
}

\author{
Raya Saba, Mahmoud Khreis, Frantz Francisque, Nasir Saleem
}

Department of Internal Medicine, Presence Saint Joseph Hospital, Chicago, Illinois, USA

\section{Correspondence to} Dr Nasir Saleem, nasirsaleemmd@gmail.com

Accepted 26 February 2016

CrossMark

\begin{tabular}{l}
\hline To cite: Saba R, Khreis M, \\
Francisque F, et al. BMJ \\
Case Rep Published online: \\
[please include Day Month \\
Year] doi:10.1136/bcr-2016- \\
214840 \\
\hline
\end{tabular}

\section{DESCRIPTION}

A 72-year-old Caucasian woman presented to the emergency department with a 1-day history of dizziness. Review of systems was significant for progressive fatigue, exercise intolerance, intermittent chills and anorexia over the preceding few weeks. She had a medical history of hypertension, hyperlipidaemia, diabetes and chronic kidney disease (stage IV; baseline creatinine $2.30 \mathrm{mg} / \mathrm{dL}$ ). Medications included cholecalciferol (2000 units by mouth daily). The patient had never smoked, did not consume alcohol and did not use illicit drugs. On physical examination, she was haemodynamically stable and had pallor and splenomegaly. Initial laboratory studies were positive for pancytopenia (white cell count $2.4 \mathrm{k} / \mathrm{mm}^{3}$; haemoglobin $8.9 \mathrm{~g} / \mathrm{dL}$ and platelets $60 \mathrm{k} / \mathrm{mm}^{3}$ ), elevated creatinine $(3.29 \mathrm{mg} / \mathrm{dL}$ ) and hypercalcaemia (calcium $14 \mathrm{mg} /$ $\mathrm{dL}$ ). The patient was admitted to the general medical floor and additional laboratory tests showed elevated C reactive protein $(2.6 \mathrm{mg} / \mathrm{dL})$, low parathyroid hormone $(9.5 \mathrm{pg} / \mathrm{mL})$, high 1,25-dihydroxyvitamin $\mathrm{D}(110 \mathrm{pg} / \mathrm{mL})$ and elevated ACE $(128 \mathrm{U} / \mathrm{L})$. Further work up was consistent with anaemia of chronic disease and no evidence of multiple myeloma. Abdominal ultrasound confirmed splenomegaly with the spleen measuring up to $23 \mathrm{~cm}$, and chest CT showing an increased number of small lymph nodes in the mediastinum and both axilla. The suspicion for malignancy was high and bone marrow biopsy was performed. The latter revealed hypercellular bone marrow at $60 \%$

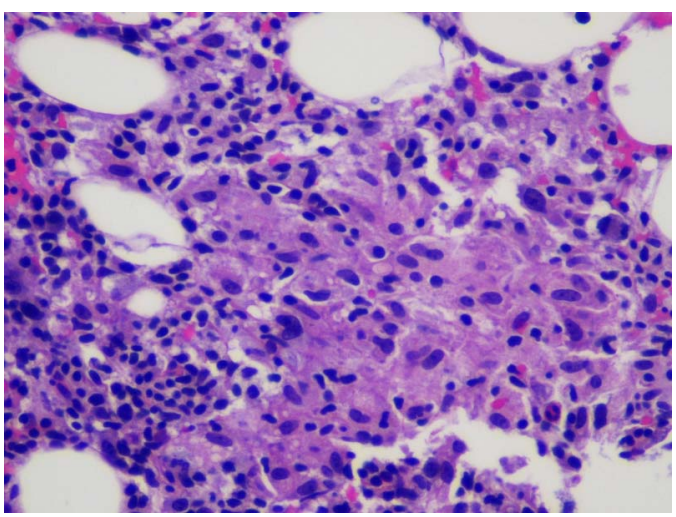

Figure 1 Bone marrow biopsy showing hypercellularity with a relatively intact trilineage haematopoiesis and a background of granulomatous inflammation.

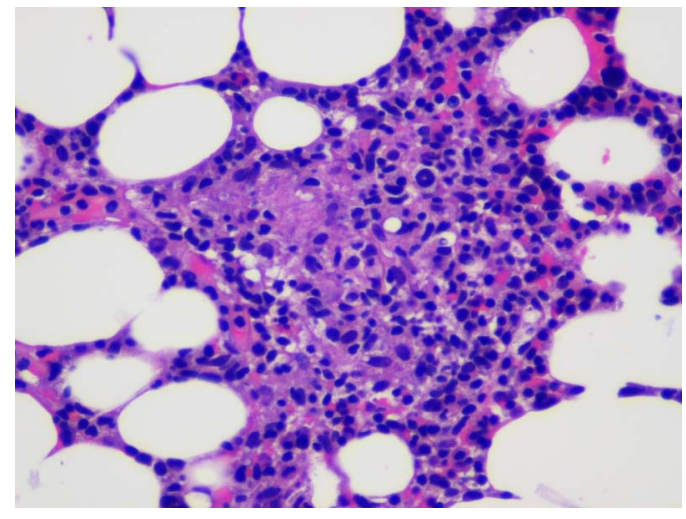

Figure 2 Bone marrow biopsy showing hypercellularity and a non-necrotising granuloma.

with relatively intact trilineage haematopoiesis and a background of granulomatous inflammation; features were suggestive of sarcoidosis (figures 1 and 2). The patient was treated with intravenous hydration (normal saline) and oral glucocorticoids (prednisone $40 \mathrm{mg}$ daily). Bisphosphonates were not initiated due to the adequate response to initial therapy. Her renal function returned to baseline and calcium level normalised $(9.8 \mathrm{mg} / \mathrm{dL})$ on discharge. She went home in stable condition after a 2-week hospital stay.

\section{Learning points}

- Sarcoidosis is a systemic inflammatory disorder of unknown aetiology, characterised by the presence of non-caseating granulomas in affected organs. ${ }^{1}$

- It can involve any organ but in more than $90 \%$ of patients it manifests with pulmonary involvement, while bone marrow involvement, acute renal failure and hypercalcaemia are rare initial presentations of the disease. ${ }^{2} 3$

- A high suspicion for sarcoidosis is warranted in patients with atypical presentations, particularly when they belong to low-risk age and ethnic groups, to allow early diagnosis and prompt institution of targeted therapy to prevent long-term sequelae of this potentially fatal condition. 
Competing interests None declared.

\section{Patient consent Obtained.}

Provenance and peer review Not commissioned; externally peer reviewed.

\section{REFERENCES}

1 Mayock RL, Bertrand P, Morrison CE, et al. Manifestations of sarcoidosis. Analysis of 145 patients, with a review of nine series selected from the literature. Am J Med 1963:35:67-89.
2 Brackers de Hugo L, Ffrench M, Broussolle C, et al. Granulomatous lesions in bone marrow: clinicopathologic findings and significance in a study of 48 cases. Eur $J$ Intern Med 2013;24:468-73.

3 Sharma N, Tariq H, Uday K, et al. Hypercalcemia, anemia, and acute kidney injury: a rare presentation of sarcoidosis. Case Rep Med 2015;2015:565243.

Copyright 2016 BMJ Publishing Group. All rights reserved. For permission to reuse any of this content visit http://group.bmj.com/group/rights-licensing/permissions.

BMJ Case Report Fellows may re-use this article for personal use and teaching without any further permission.

Become a Fellow of BMJ Case Reports today and you can:

- Submit as many cases as you like

- Enjoy fast sympathetic peer review and rapid publication of accepted articles

- Access all the published articles

- Re-use any of the published material for personal use and teaching without further permission

For information on Institutional Fellowships contact consortiasales@bmjgroup.com

Visit casereports.bmj.com for more articles like this and to become a Fellow 